\title{
Temporal and Spatial Physico-Chemical Parameters of Kubanni Dam, Galma Dam and Shika Dam, Zaria, Kaduna State, Nigeria
}

\author{
E.A. Aregbe ${ }^{1 *}$, O. S. Olonitola ${ }^{1}$, H.I. Inabo ${ }^{1}$, E.E. Ella ${ }^{1}$ and V.C. Ameso ${ }^{2}$ \\ ${ }^{1}$ Department of Microbiology, ${ }^{2}$ Department of Water Resources and Environmental \\ Management, Ahmadu Bello University, Zaria, Nigeria \\ *Corresponding author
}

\begin{tabular}{l} 
Ke y w or d s \\
$\begin{array}{l}\text { Physico-chemical } \\
\text { parameters, } \\
\text { Drinking water, } \\
\text { Turbidity, COD and } \\
\text { hardness }\end{array}$ \\
\hline Article Info \\
\hline $\begin{array}{l}\text { Accepted: } \\
\text { 06 July } 2018 \\
\text { Available Online: } \\
\text { 10 August } 2018\end{array}$ \\
\hline
\end{tabular}

\section{A B S T R A C T}

The temporal and spatial physico-chemical parameters of Kubanni dam, Galma dam and Shika Dam was carried out between October, 2016 to July, 2017 for the determination of twelve physico-chemical parameters on monthly basis following standard methods. The results indicates high significant difference $(\mathrm{p}<0.05)$ amongst most of parameters tested for the sampling locations except for Hardness, Biochemical Oxygen Demand and color. The conductivity of water samples from the three dams ranged $133.97 \pm 30.33$ (A.B.U dam) to $148.80 \pm 22.64 \mu \mathrm{S} / \mathrm{cm}$ (Shika dam) while $\mathrm{pH}$ ranged from 7.15 \pm 0.20 (Shika dam) to $7.39 \pm 0.22$ (Galma dam), Alkalinity ranged from $35.91 \pm 11.51 \mathrm{mg} / \mathrm{l}$ (Galma dam) to $41.83 \mathrm{mg} / \mathrm{l}$ (A.B.U dam). Turbidity ranged from $20.18 \pm 26.17$ (Shika dam) to 37.39 \pm 35.69 ) NTU

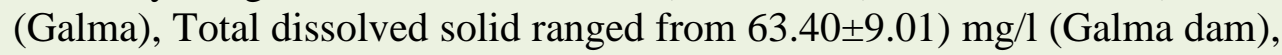
to $70.64 \pm 6.99$ (Shika dam), Chemical oxygen demand ranged from $238.80 \pm 48.95 \mathrm{mg} / 1$ Galma to $274.25 \pm 97.90 \mathrm{mg} / 1$ A.B.U dam, dissolved oxygen ranges from $1.54 \pm 0.56 \mathrm{mg} / \mathrm{l}$, (Shika dam) to $1.81 \pm 0.42$ (Galma dam), Chloride ranged from $12.62 \pm 2.35$ (Galma dam) $\mathrm{mg} / \mathrm{l}$ to $18.03 \pm 3.57$ (Shika dam), and Temperature ranged from $26.05 \pm 1.41^{\circ} \mathrm{C}$ (Galma) to $26.33 \pm 1.18$ (Shika dam). The parameters were within the World Health Organization and Nigerian Standard for Drinking Water Quality limits except for turbidity, COD and hardness. Generally the water samples from Shika dam were observed to be hard while Galma dam was found to be most turbid.

\section{Introduction}

Water is one of the most important and abundant compounds of the ecosystem. All living organisms on the earth need water for their survival and growth. As of now only earth is the planet having about $70 \%$ of water. The availability of good quality water is an indispensable feature for preventing diseases and improving quality of life. Natural water 
contains different types of impurities which are introduced in to aquatic system through different means such as weathering of rocks and leaching of soils, dissolution of aerosol particles from the atmosphere and from several human activities, including mining, processing and the use of metal based materials (Patil et al., 2012). It is very essential and important to test the water before it is used for drinking, domestic, agricultural or industrial purpose. Water must be tested with different physic-chemical parameters. Selection of parameters for testing of water is solely depends upon for what purpose we going to use that water and what extent we need its quality and purity (Patil et al., 2012). Water does contain several floating, dissolved, suspended and microbiological as well as bacteriological impurities. Some physical test should be performed for physical testing such as temperature, color, odour, $\mathrm{pH}$, turbidity, TDS etc, while chemical tests should be perform for its BOD, COD, dissolved oxygen, alkalinity, hardness and other characters. Temperature is the most important environment factor with effect on plants and animals.

The Water temperature depends on the depth of the water column, climatic and topographic changes (Sagar et al., 2015). $\mathrm{pH}$ is one of the most common analyses in soil and water testing, it is the standard measure of how acidic or alkaline a solution is. It can be measured with a scale from $0-14$. $\mathrm{pH}$ of 7 is neutral, $\mathrm{pH}$ is less than 7 is acidic and $\mathrm{pH}$ greater than 7 is basic (Patil et al., 2012). Electrical conductivity (EC) is a measure of the electric current that solution carries. It is used to estimate the ionic or soluble salt concentration in soils, water supplies, fertilizer solution and chemical solution (Sagar et al., 2015). Alkalinity is a chemical measurement of water's ability to neutralize acid. It is due to the presence of weak acid salts, although strong bases may also contribute (i.e. $\mathrm{OH}-$ ) in the extreme environment (Sagar et al., 2015). Dissolved oxygen is the most important indicator of the health of water bodies and its capacity to support a balanced aquatic ecosystem of plants and animals (Adefemi and Awokunmi, 2010).

Total hardness is defined as the sum of calcium and magnesium hardness in $\mathrm{mg} / \mathrm{L}$.It is the total amount of mobile charged ions, including minerals, salts or metal dissolved in a given volume of water in $\mathrm{mg} / \mathrm{L}$. (Patil et al., 2012). The chemical oxygen demand test procedure is based on the chemical decomposition of organic and inorganic contaminants, dissolved or suspended in water. A low value of DO and higher values of BOD and COD can be as a result of the discharge of effluents and non-point source of pollution (Maheshkumar and Prabhahar, 2012).

Biochemical oxygen measures the amount of oxygen that microorganisms consume.BOD is a measure of organic matter contamination in water, specified in mg/L. (Sagar et al., 2015). Chloride, the ionized form of chlorine, is one of the most abundant inorganic ions in natural water and wastewater. Excess chloride in water leads to stomach discomfort, Eye/nose irritation (Sagar et al., 2015). The physicochemical analysis is a fundamental tool necessary for the management of freshwater resources, particularly rivers, streams and dams which are often than not the main sources of drinking water in the rural and some urban areas (Adah and Abok, 2013).

\section{Materials and Methods}

\section{Study area}

The study was conducted in Kaduna State, Nigeria in three selected dams: The Galma dam, The Kubanni dam and The Shika dam. 


\section{Collection of samples}

The water samples were collected in three different dams in Kaduna State, Nigeria which included the Galma dam, the Kubanni dam and the shika dam. A total of 450 water samples were taken from the three dams during a 10 month period. Using $5 \mathrm{~L}$ sterile plastic containers, raw water samples were collected from the reservoirs. The water samples were collected in batches and each batch of the samples were taken to the laboratory for physicochemical analyses.

\section{Physicochemical analysis of water samples}

A bench top $\mathrm{pH}$ meter $\mathrm{HI}-2210-02$ was used to measure the $\mathrm{pH}$ of water using standard protocols. Temperature was taken and determined in the laboratory using Hana instrument (HI98129 Model) which was calibrated in ${ }^{0} \mathrm{C}$ and was used to determine the conductivity and total dissolved solids of the water samples. Total hardness was determined using standard titration method using Twenty five $\mathrm{ml}$ of distilled water was added to $25 \mathrm{ml}$ of water sample in a conical flask. Two $\mathrm{ml}$ buffer solution of $\mathrm{pH} 10.4$ was added; followed by addition of 0.1g Eriochrome black $\mathrm{T}$ dye and titrated with EDTA titrant (0.01Molar). The volume of EDTA used was noted and the hardness of water sample in ppm $\left(\right.$ as $\left.\mathrm{CaCO}_{3}\right)$ calculated. Total Alkalinity was determined using standard titrimetric method (APHA,2012).One hundred $\mathrm{ml}$ of water sample was transferred into a conical flask with two drops of phenolphthalein indicator which was titrated with $0.02 \mathrm{~N} \mathrm{H}_{2} \mathrm{SO}_{4}$ and a pink color was observed. Thereafter, two drops of bromocresol green and two drops of methyl red was added. The mixture was swirled and titrated with same solution of $0.02 \mathrm{~N} \mathrm{H}_{2} \mathrm{SO}_{4}$ until colour change was observed from pink to yellow (APHA, 2012). Biochemical Oxygen Demand (BOD) and Dissolved Oxygen (DO) was determined using the wrinkler method (Radojeri and Baskin, (1999).

\section{Data analysis}

The results were presented inform of tables, charts, graphs, and analyzed using One way ANOVA (Analysis of variance) followed by Duncan Multiple Range (DMRT) test for mean separation, $\mathrm{p} \leq 0.05$ to determine the differences between the mean sampling locations and months using SPSS IBM (Version 20 for window) statistical package at $\mathrm{P}<0.05$ level of significance.

\section{Results and Discussion}

From the ANOVA and (DMRT) analysis the physicochemical parameters of water samples from the three dams (Shika, A.B.U and Galma dam) in Table 1 indicates significant difference amongst most of parameters tested for the sampling locations except for Hardness, Biochemical Oxygen Demand and color. The conductivity of water samples from the three dams ranged $133.97 \pm 30.33$ (A.B.U dam) to $148.80 \pm 22.64 \mu \mathrm{S} / \mathrm{cm}$ (Shika dam) while $\mathrm{pH}$ ranged from $7.15 \pm 0.20$ (Shika dam) to $7.39 \pm 0.22$ (Galma dam), Alkalinity ranged from $35.91 \pm 11.51 \mathrm{mg} / \mathrm{l}$ (Galma dam) to 41.83 $\mathrm{mg} / \mathrm{l}$ (A.B.U dam). Turbidity ranged from $20.18 \pm 26.17$ (Shika dam) to $37.39 \pm 35.69$ ) NTU (Galma), Total dissolved solid ranged from $63.40 \pm 9.01) \mathrm{mg} / \mathrm{l}$ (Galma dam), to $70.64 \pm 6.99$ (Shika dam), Chemical oxygen demand ranged from $238.80 \pm 48.95 \mathrm{mg} / \mathrm{l}$ Galma to $274.25 \pm 97.90 \mathrm{mg} / \mathrm{l}$ A.B.U dam, dissolved oxygen ranges from $1.54 \pm 0.56 \mathrm{mg} / \mathrm{l}$, (Shika dam) to $1.81 \pm 0.42$ (Galma dam), Chloride ranged from 12.62 \pm 2.35 (Galma dam) $\mathrm{mg} / \mathrm{l}$ to $18.03 \pm 3.57$ (Shika dam), Hardness ranged from $233.46 \pm 82.10$ Galma to $238.55 \pm 104.31 \mathrm{mg} / \mathrm{l}$ Shika and Temperature ranged from $26.05 \pm 1.41^{\circ} \mathrm{C}$ (Galma) to $26.33 \pm 1.18$ (Shika dam) (Table 2). The mean monthly physicochemical properties of water 
samples for A.B.U dam in Table 3 showed there were high significant differences in all the parameters for Turbidity, dissolved oxygen, BOD, COD, $\mathrm{pH}$, color, temperature, total dissolved solid, hardness alkalinity, chloride and electrical conductivity tested for the sampling months. The analysis of the mean monthly physicochemical properties of water samples for Galma dam. There were significant differences in all the parameters for Turbidity, dissolved oxygen BOD COD, $\mathrm{pH}$, color, temperature, total dissolved solid, hardness alkalinity, chloride and electrical conductivity tested for the sampling month Table 4 showed the analysis of results for the mean monthly physicochemical properties of water samples for Shika dam. There were significant difference in Turbidity, dissolved oxygen $\mathrm{BOD}, \mathrm{pH}$, color, temperature, total dissolved solid hardness alkalinity, chloride and electrical conductivity tested for the sampling months. There was no significant difference in COD of the sampling months. The Turbidity ranged from 6.19 (May) to 93.55 (June), dissolved oxygen ranged from 0.91 (January) to 2.26 (June), BOD ranged from 0.43 (February) to 1.22 (June) $\mathrm{pH}$ ranged from 6.94 (October) to 7.29 (January), Temperature ranged from 24.76 (December) to 27.59 (April), TDS ranged from 59.20 (June) to 78.47 (May), Hardness ranged from 131.31 (June) to 348.82 (February), Alkalinity ranged from 30.93 (March) to 64.73 (June), Chloride ranged from 14.34 (November) to 22.33 (December) and electrical conductivity ranged from116.60 (June) to176.67 (May).

Water is one of the most important and abundant compounds of the ecosystem. All living organisms on the earth need water for their survival and growth (Patil et al., 2012). The locations for the three dams showed no significant difference for BOD, hardness and color. However there were significant difference amongst the parameters for the locations and monthly variations for the three dams. The water temperature range for the three reservoir was within the normal range for water. High water temperature could affect metabolic activities of microorganisms and aquatic life (Banwo, 2006). The result compares well with Okunlola et al., (2014), Oyakhilome et al., (2012) which had mean temperature values within the optimal range. $\mathrm{pH}$ is classed as one of the most important water quality parameters. The normal raw water $\mathrm{pH}$ is between 6.5 and 8.5. The $\mathrm{pH}$ values of all the three dam water samples were found to be neutral throughout the location this range is typical of most major drainage basins of the world Genevieve and James 2006. Turbidity is the cloudiness of water caused by a variety of particles and is another key parameter in water quality analysis. It is related to the content of diseases causing organisms in water, which may come from soil runoff (Basavaraja et al., 2011).

The turbidity measured for locations was high in all the dams which could be attributed to the presence of organic matter pollution, other effluents like the domestic and industrial, runoff with high suspended particles discharged in the reservoir especially during the torrential rains in the wet season. Turbidity values reported for most dams in Nigeria were far greater than 5.0 NTU limit given by NSDWQ (2007), Ajibade (2004), WHO (2008), Wakawa et al., (2008) which could lead to unpleasant taste and odours, increase in the amount of disinfection by products Trihalomethanes (THMs) that form in treated water and could interfere with sunlight penetration, thus reducing photosynthesis and the production of oxygen for fish and aquatic life (Oyakhilome et al., 2012). The location and months for total dissolved solids levels for all samples were below the maximum permissible limit of $600 \mathrm{mg} / 1$ (NSDWQ, 2007) and (WHO, 2008). The low TDS values measured reflect freshness of the water source (Oyakhilome et al., 2012). 
Table.1 The mean physicochemical parameter of water samples from three selected dams in Kaduna State

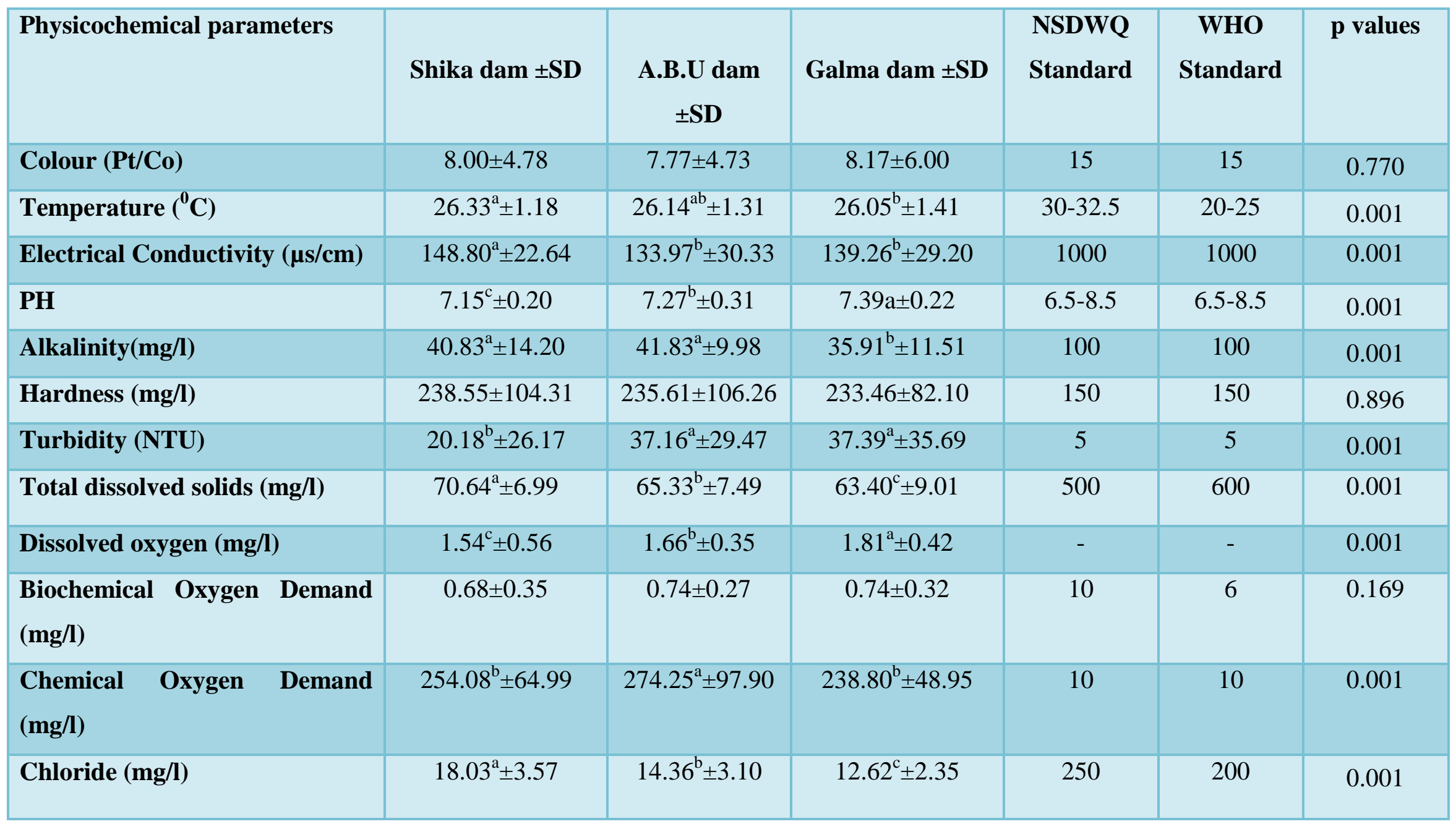

superscripts with the same letters in each row are not significantly different $\mathrm{p} \geq 0.05$, KEY: Nigerian standard for drinking water quality (NSDWQ),World Health Organization (WHO) and Standard deviation (SD) 
Table.2 Mean monthly physicochemical properties of water samples for A.B.U dam in Kaduna State

\begin{tabular}{|c|c|c|c|c|c|c|c|c|c|c|c|}
\hline Parameter & $\begin{array}{l}\text { October } \\
2016\end{array}$ & $\begin{array}{l}\text { November } \\
2016\end{array}$ & $\begin{array}{l}\text { December } \\
2016\end{array}$ & $\begin{array}{l}\text { January } \\
2017\end{array}$ & $\begin{array}{l}\text { February } \\
2017\end{array}$ & $\begin{array}{l}\text { March } \\
2017\end{array}$ & $\begin{array}{l}\text { April } \\
2017\end{array}$ & $\begin{array}{l}\text { May } \\
2017\end{array}$ & $\begin{array}{l}\text { June } \\
2017\end{array}$ & $\begin{array}{l}\text { July } \\
2017\end{array}$ & $\begin{array}{l}\text { p- } \\
\text { value }\end{array}$ \\
\hline Turbidity(NTU) & $58.89^{b}$ & $39.85^{\mathrm{c}}$ & $32.51^{\mathrm{cd}}$ & $25.76^{\mathrm{de}}$ & $19.12^{\mathrm{ef}}$ & $12.30^{f}$ & $12.73^{f}$ & $11.88^{\mathrm{f}}$ & $98.80^{\mathrm{a}}$ & $59.73^{b}$ & $<0.001$ \\
\hline DO (Mg/l) & $1.75^{\mathrm{ab}}$ & $1.31^{\mathrm{c}}$ & $1.39^{c}$ & $1.42^{\mathrm{c}}$ & $1.71^{\mathrm{b}}$ & $1.75^{\mathrm{ab}}$ & $1.77^{\mathrm{ab}}$ & $1.68^{\mathrm{b}}$ & $1.89^{\mathrm{ab}}$ & $1.93^{\mathrm{a}}$ & $<0.001$ \\
\hline BOD (Mg/l) & $0.99^{\mathrm{a}}$ & $0.59^{\mathrm{de}}$ & $0.62^{\text {cde }}$ & $0.56^{\mathrm{e}}$ & $0.65^{\text {cde }}$ & $0.77^{\text {bcd }}$ & $0.73^{\text {cde }}$ & $0.71^{\text {cde }}$ & $0.91^{\mathrm{ab}}$ & $0.82^{\mathrm{abc}}$ & $<0.001$ \\
\hline COD (Mg/l) & $365.79^{\mathrm{a}}$ & $206.00^{c}$ & $257.30^{c}$ & $268.67^{b c}$ & $244.67^{c}$ & $241.33^{c}$ & $267.33 b c$ & $279.33 b c$ & 337.33ab & $274.67^{b c}$ & $<0.002$ \\
\hline PH & $7.13^{\mathrm{e}}$ & $7.18^{\mathrm{de}}$ & $7.27^{\text {cde }}$ & $7.34 b^{\mathrm{cd}}$ & $7.44^{\mathrm{abc}}$ & $7.57^{\mathrm{a}}$ & $7.51^{\mathrm{ab}}$ & $7.43^{a b c}$ & $6.90^{f}$ & $6.93^{f}$ & $<0.001$ \\
\hline Colour (Pt/Co) & $18.33^{\mathrm{a}}$ & $13.33^{\mathrm{b}}$ & $6.67^{\mathrm{d}}$ & $5.00^{e}$ & $5.00^{\mathrm{e}}$ & $5.00^{\mathrm{e}}$ & $5.00^{\mathrm{e}}$ & $5.00^{\mathrm{e}}$ & $9.33^{\mathrm{c}}$ & $5.00^{\mathrm{e}}$ & $<0.001$ \\
\hline $\begin{array}{l}\text { Temperature } \\
0^{0} \mathrm{C}\end{array}$ & $26.87^{b c}$ & $26.45^{\mathrm{c}}$ & $24.41^{\mathrm{de}}$ & $24.21^{\mathrm{e}}$ & $24.86^{\mathrm{d}}$ & $26.85^{\mathrm{bc}}$ & $27.47^{\mathrm{a}}$ & $26.52^{c}$ & $26.65^{b c}$ & $27.09^{\mathrm{ab}}$ & $<0.001$ \\
\hline TDS (Mg/l) & $58.73^{\mathrm{e}}$ & $55.73^{\mathrm{f}}$ & $56.40^{\mathrm{ef}}$ & $62.07^{\mathrm{d}}$ & $66.67^{\mathrm{c}}$ & $67.67^{\mathrm{c}}$ & $65.73^{\mathrm{c}}$ & $70.80^{b}$ & $73.73^{\mathrm{a}}$ & $75.73^{\mathrm{a}}$ & $<0.001$ \\
\hline Hardness (Mg/l) & $123.23^{\mathrm{d}}$ & $167.00^{c}$ & $147.47^{\mathrm{cd}}$ & $243.09^{b}$ & $331.24^{\mathrm{a}}$ & $256.90^{\mathrm{a}}$ & $353.53^{\mathrm{a}}$ & $358.92^{\mathrm{a}}$ & $122.56^{\mathrm{d}}$ & $152.18^{\mathrm{cd}}$ & $<0.001$ \\
\hline Alkalinity(Mg/l) & $41.87^{\mathrm{b}}$ & $37.53^{b}$ & $41.40^{b}$ & $36.67^{b}$ & $43.13^{b}$ & $42.13^{b}$ & $38.33^{\mathrm{b}}$ & $38.87^{\mathrm{b}}$ & $54.33^{\mathrm{a}}$ & $44.00^{\mathrm{b}}$ & $<0.001$ \\
\hline Chloride (Mg/l) & $11.40^{\mathrm{g}}$ & $11.00^{\mathrm{g}}$ & $13.23^{\mathrm{ef}}$ & $12.06^{\mathrm{tg}}$ & $13.76^{\mathrm{e}}$ & $16.23^{b c}$ & $18.36^{\mathrm{a}}$ & $17.30^{\mathrm{ab}}$ & $14.53^{\mathrm{de}}$ & $15.69^{\mathrm{cd}}$ & $<0.001$ \\
\hline $\mathrm{EC}(\boldsymbol{\mu s} / \mathbf{c m})$ & $100.67^{\mathrm{e}}$ & $110.27^{\mathrm{d}}$ & $114.07^{\mathrm{d}}$ & $136.07^{\mathrm{c}}$ & $161.33^{b}$ & $167.27^{\mathrm{ab}}$ & $161.53^{b}$ & $174.20^{\mathrm{a}}$ & $100.47^{\mathrm{e}}$ & $113.80^{d}$ & $<0.001$ \\
\hline
\end{tabular}

For each parameter means with the different letters (superscripts) are significantly different ( $\mathrm{p}<0.05$ ), using Duncan multiple range test for mean separation

Key: DO=Dissolved oxygen, $\mathrm{BOD}=$ Biochemical oxygen demand, $\mathrm{COD}=\mathrm{Chemical}$ oxygen demand and $\mathrm{EC}=\mathrm{Electrical}$ conductivity.SD=Standard deviation, TDS=Total dissolved solids 
Table.3 Mean monthly physicochemical properties of water samples for Galma dam in Kaduna State

\begin{tabular}{|c|c|c|c|c|c|c|c|c|c|c|c|}
\hline Parameter & $\begin{array}{l}\text { October } \\
2016\end{array}$ & $\begin{array}{l}\text { November } \\
2016\end{array}$ & $\begin{array}{l}\text { December } \\
2016\end{array}$ & $\begin{array}{l}\text { January } \\
2017\end{array}$ & $\begin{array}{l}\text { February } \\
2017\end{array}$ & $\begin{array}{l}\text { March } \\
2017\end{array}$ & $\begin{array}{l}\text { April } \\
2017\end{array}$ & $\begin{array}{l}\text { May } \\
2017\end{array}$ & $\begin{array}{l}\text { June } \\
2017\end{array}$ & $\begin{array}{l}\text { July } \\
2017\end{array}$ & $\begin{array}{l}p \text { - } \\
\text { value }\end{array}$ \\
\hline Turbidity(NTU) & $128.85^{\mathrm{a}}$ & $31.07^{\mathrm{b}}$ & $22.13^{c}$ & $22.16^{\mathrm{d}}$ & $21.03^{d}$ & $16.95^{\mathrm{d}}$ & $18.25^{\mathrm{d}}$ & $19.63^{d}$ & $71.25^{\mathrm{b}}$ & $22.53^{d}$ & $<0.001$ \\
\hline DO $(\mathrm{Mg} / \mathrm{l})$ & $2.01^{\mathrm{abc}}$ & $1.41^{\mathrm{d}}$ & $1.34^{\mathrm{d}}$ & $1.51^{\mathrm{d}}$ & $1.78^{c}$ & $2.06^{\mathrm{ab}}$ & $1.84^{\mathrm{bc}}$ & $1.93^{\mathrm{bc}}$ & $2.05^{\mathrm{ab}}$ & $2.21^{\mathrm{a}}$ & $<0.001$ \\
\hline BOD (Mg/l) & $0.86^{\mathrm{b}}$ & $0.55^{\mathrm{d}}$ & $0.57^{\text {cd }}$ & $0.53^{d}$ & $0.65^{\mathrm{cd}}$ & $0.77^{\mathrm{bc}}$ & $0.70^{\text {bcd }}$ & $0.59^{\text {cd }}$ & $1.06^{\mathrm{a}}$ & $1.11^{\mathrm{a}}$ & $<0.001$ \\
\hline COD (Mg/l) & $264.67^{\mathrm{a}}$ & $228.00^{\mathrm{ab}}$ & $232.00^{\mathrm{ab}}$ & $258.00^{\mathrm{ab}}$ & $230.00^{\mathrm{ab}}$ & $228.00^{\mathrm{ab}}$ & $240.00^{\mathrm{ab}}$ & $260.67^{a}$ & $220.00^{b}$ & $226.67^{\mathrm{ab}}$ & $<0.090$ \\
\hline PH & $7.35^{\mathrm{bc}}$ & $7.36^{\mathrm{bc}}$ & $7.50^{\mathrm{a}}$ & $7.58^{\mathrm{a}}$ & $7.53^{\mathrm{a}}$ & $7.45^{\mathrm{ab}}$ & $7.50^{\mathrm{a}}$ & $7.28^{c}$ & $7.25^{\mathrm{cd}}$ & $7.17^{\mathrm{d}}$ & $<0.001$ \\
\hline Colour (Pt/Co) & $23.33^{\mathrm{a}}$ & $13.33^{b}$ & $5.00^{d}$ & $5.00^{d}$ & $5.00^{d}$ & $5.00^{d}$ & $5.00^{\mathrm{d}}$ & $5.00^{d}$ & $8.33^{c}$ & $5.00^{d}$ & $<0.001$ \\
\hline Temperature $0^{0} \mathrm{C}$ & $26.51^{\mathrm{abc}}$ & $26.38^{b c}$ & $24.59^{d}$ & $24.39^{d}$ & $24.81^{\mathrm{d}}$ & $26.54^{\mathrm{abc}}$ & $27.31^{\mathrm{a}}$ & $26.63^{\mathrm{abc}}$ & $26.17^{\mathrm{abc}}$ & $27.17^{\mathrm{ab}}$ & $<0.001$ \\
\hline TDS (Mg/l) & $50.33^{\mathrm{f}}$ & $59.73^{\mathrm{de}}$ & $56.67^{\mathrm{e}}$ & $61.13^{b c d}$ & $60.40^{\text {cde }}$ & $63.73^{b c}$ & $64.60^{b}$ & $65.00^{\mathrm{b}}$ & $77.21^{\mathrm{a}}$ & $75.13^{\mathrm{a}}$ & $<0.001$ \\
\hline Hardness (Mg/l) & $129.96^{\mathrm{f}}$ & $175.75^{d}$ & $136.02^{\mathrm{ef}}$ & $254.54^{\mathrm{c}}$ & $327.94^{\mathrm{a}}$ & $274.07^{b c}$ & $275.42^{b c}$ & $305.05^{\mathrm{ab}}$ & $162.96^{\text {de }}$ & $292.93^{b}$ & $<0.001$ \\
\hline Alkalinity(Mg/l) & $34.53^{b c}$ & $35.80^{\mathrm{b}}$ & $34.47^{b c}$ & $26.47^{\mathrm{d}}$ & $28.80^{\mathrm{cd}}$ & $31.13^{\mathrm{bcd}}$ & $31.13^{\text {bcd }}$ & $31.60^{\mathrm{bcd}}$ & $52.07^{\mathrm{a}}$ & $53.13^{\mathrm{a}}$ & $<0.001$ \\
\hline Chloride (Mg/l) & $11.93^{b}$ & $13.76^{\mathrm{a}}$ & $13.43^{\mathrm{a}}$ & $9.43^{c}$ & $10.33^{c}$ & $12.73^{\mathrm{ab}}$ & $13.63^{\mathrm{a}}$ & $13.53^{\mathrm{a}}$ & $13.50^{\mathrm{a}}$ & $13.89^{\mathrm{a}}$ & $<0.001$ \\
\hline $\mathrm{EC}(\boldsymbol{\mu s} / \mathbf{c m})$ & $96.68^{\mathrm{g}}$ & $119.87^{\mathrm{ef}}$ & $114.53^{\mathrm{f}}$ & $144.87^{\text {bcd }}$ & $155.80^{\mathrm{abc}}$ & $164.80^{\mathrm{a}}$ & $159.67^{b}$ & $164.60^{\mathrm{a}}$ & $130.87^{\mathrm{de}}$ & $140.93^{\mathrm{cd}}$ & $<0.001$ \\
\hline
\end{tabular}

For each parameter means with the different letters (superscripts) are significantly different $(\mathrm{p}<0.05$ ), using Duncan multiple range test for mean separation Key: $\mathrm{DO}=$ Dissolved oxygen, $\mathrm{BOD}=$ Biochemical oxygen demand, $\mathrm{COD}=$ Chemical oxygen demand and $\mathrm{EC}=$ Electrical conductivity. $\mathrm{SD}=\mathrm{Standard}$ deviation, TDS=Total dissolved solid 
Table.4 Mean monthly physicochemical properties of water samples for Shika dam in Kaduna State

\begin{tabular}{|c|c|c|c|c|c|c|c|c|c|c|c|}
\hline Parameter & $\begin{array}{l}\text { October } \\
2016\end{array}$ & $\begin{array}{l}\text { November } \\
2016\end{array}$ & $\begin{array}{l}\text { December } \\
2016\end{array}$ & $\begin{array}{l}\text { January } \\
2017\end{array}$ & $\begin{array}{l}\text { February } \\
2017\end{array}$ & $\begin{array}{l}\text { March } \\
2017\end{array}$ & $\begin{array}{l}\text { April } \\
2017\end{array}$ & $\begin{array}{l}\text { May } \\
2017\end{array}$ & $\begin{array}{l}\text { June } \\
2017\end{array}$ & $\begin{array}{l}\text { July } \\
2017\end{array}$ & $\begin{array}{l}\text { P- } \\
\text { value }\end{array}$ \\
\hline Turbidity(NTU) & $15.75^{\mathrm{bc}}$ & $19.73^{\mathrm{b}}$ & $19.48^{\mathrm{b}}$ & $10.16^{\mathrm{cd}}$ & $10.27^{\mathrm{cd}}$ & $6.82^{\mathrm{d}}$ & $6.68^{d}$ & $6.19^{d}$ & $93.55^{\mathrm{a}}$ & $13.14^{\mathrm{c}}$ & $<0.001$ \\
\hline DO (Mg/l) & $2.22^{\mathrm{ab}}$ & $1.38^{\mathrm{c}}$ & $1.11^{\mathrm{d}}$ & $0.91^{\mathrm{d}}$ & $1.03^{\mathrm{d}}$ & $1.50^{\mathrm{c}}$ & $1.47^{\mathrm{c}}$ & $1.48^{\mathrm{c}}$ & $2.26^{\mathrm{a}}$ & $2.00^{\mathrm{b}}$ & $<0.001$ \\
\hline BOD (Mg/l) & $1.05^{\mathrm{b}}$ & $0.80^{\mathrm{c}}$ & $0.50^{\mathrm{d}}$ & $0.47^{\mathrm{d}}$ & $0.43^{\mathrm{d}}$ & $0.50^{\mathrm{d}}$ & $0.45^{\mathrm{d}}$ & $0.47^{\mathrm{d}}$ & $1.22^{\mathrm{a}}$ & $0.90^{\mathrm{bc}}$ & $<0.001$ \\
\hline COD (Mg/l) & 230.00 & 274.00 & 247.33 & 262.00 & 253.33 & 263.33 & 264.00 & 267.33 & 242.67 & 236.67 & $<0.682$ \\
\hline PH & $6.94^{\mathrm{c}}$ & $7.11^{b}$ & $7.07^{\mathrm{b}}$ & $7.29^{a}$ & $7.25^{\mathrm{a}}$ & $7.19^{\mathrm{ab}}$ & $7.11^{b}$ & $7.17^{\mathrm{ab}}$ & $7.09^{\mathrm{ab}}$ & $7.15^{\mathrm{ab}}$ & $<0.001$ \\
\hline Colour (Pt/Co) & $18.33^{\mathrm{a}}$ & $13.33^{b}$ & $6.67^{\mathrm{d}}$ & $5.00^{\mathrm{e}}$ & $5.00^{\mathrm{e}}$ & $5.00^{\mathrm{e}}$ & $5.00^{e}$ & $5.00^{e}$ & $11.67^{\mathrm{c}}$ & $5.00^{\mathrm{e}}$ & $<0.001$ \\
\hline Temperature $0^{0} \mathrm{C}$ & $26.50^{\mathrm{cd}}$ & $26.77^{b c}$ & $24.76^{\mathrm{e}}$ & $25.29^{\mathrm{e}}$ & $25.35^{\mathrm{e}}$ & $27.20^{\mathrm{ab}}$ & $27.59^{\mathrm{a}}$ & $26.23^{\mathrm{d}}$ & $26.57^{\text {bcd }}$ & $27.07^{\mathrm{abc}}$ & $<0.001$ \\
\hline TDS (Mg/l) & $66.33^{c}$ & $66.47^{\mathrm{c}}$ & $73.40^{b}$ & $73.67^{b}$ & $72.93^{b}$ & $74.6^{\mathrm{b}}$ & $75.00^{\mathrm{b}}$ & $78.47^{\mathrm{a}}$ & $59.20^{\mathrm{d}}$ & $66.33^{c}$ & $<0.001$ \\
\hline Hardness (Mg/l) & $137.37^{c}$ & $167.40^{c}$ & $139.39^{c}$ & $288.88^{b}$ & $348.82^{\mathrm{a}}$ & $329.96^{\mathrm{a}}$ & $331.98^{\mathrm{a}}$ & $350.16^{\mathrm{a}}$ & $131.31^{c}$ & $160.26^{c}$ & $<0.001$ \\
\hline Alkalinity(Mg/l) & $53.67^{b}$ & $37.07^{\mathrm{c}}$ & $37.80^{\mathrm{c}}$ & $32.87^{\mathrm{c}}$ & $34.20^{\mathrm{c}}$ & $30.93^{c}$ & $32.33^{\mathrm{c}}$ & $33.27^{\mathrm{c}}$ & $64.73^{\mathrm{a}}$ & $51.40^{\mathrm{b}}$ & $<0.001$ \\
\hline Chloride (Mg/l) & $16.03^{\mathrm{de}}$ & $14.34^{\mathrm{e}}$ & $22.33^{\mathrm{a}}$ & $16.06^{\mathrm{de}}$ & $16.93^{\mathrm{cd}}$ & $20.03^{b}$ & $20.10^{\mathrm{b}}$ & $18.83^{\mathrm{bc}}$ & $17.56^{\mathrm{cd}}$ & $18.06^{\mathrm{bcd}}$ & $<0.001$ \\
\hline $\mathrm{EC}(\boldsymbol{\mu s})$ & $124.71^{d}$ & $130.80^{d}$ & $145.27^{c}$ & $147.80^{c}$ & $172.53^{\mathrm{ab}}$ & $167.47^{b}$ & $165.60^{b}$ & $176.67^{\mathrm{a}}$ & $116.60^{\mathrm{e}}$ & $140.60^{c}$ & $<0.001$ \\
\hline
\end{tabular}

For each parameter means with the different letters (superscripts) are significantly different ( $\mathrm{p}<0.05$ ), using Duncan multiple range test for mean separation Key: DO=Dissolved oxygen, BOD=Biochemical oxygen demand, $\mathrm{COD}=\mathrm{Chemical}$ oxygen demand and EC=Electrical conductivity.SD=Standard deviation, TDS=Total dissolved solid 
Water hardness was high for shika dam sampling location. Most of the samples indicate that they are above the permissible limit of 150mg/l (NSDWQ, 2007) and 200mg/l (WHO, 2008) which is regarded as poor. According to Hardness Classification of Water by Sawyer and McCarty quoted in Todd and Mays (2005), dam water is classified as hard. This might be due to the presence of dissolved $\mathrm{Ca}^{2+}$ and $\mathrm{Mg}^{2+}$ ions and high concentration of hardness may cause the problem of heart disease and kidney stone (Sagar et al., 2015). The electrical conductivity value obtained shows that the Shika dam have value higher than that the other dams for location. The mean values of electrical conductivity of the water were high during the month of May for the three dams, which could be attributed to dilution factor as a result of increased water volume from their main tributary channels and the main water stream. Low values were obtained during the month of October which may have been as a result of increased water concentration due to low water level resulting to siltation since it is an impounded dam.. However, all the values obtained were within the permissible limit of 1000mg/l (NSDWQ, 2007) and (WHO, 2008). Biochemical Oxygen Demand (BOD) and Chemical Oxygen Demand (COD) are two common measures of water quality that reflect the degree of organic matter pollution of a water body (Genevieve and James, 2006). The BOD values for the three locations were low and indicative of high dissolved oxygen concentrations. The high level of COD in the dams could be as a result of leachate from dumpsites, agricultural and urban runoff, discharge of effluents and non-point source of pollution which comes from different sources as a result of rain fall, waste from mechanic workshops and battery charging shops, (Sagar et al., 2015). The mean monthly physicochemical properties of water samples for A.B.U dam showed variations in the parameters tested and were significant except for the COD. The variations could be due to the location of the dam, the time of collection and the activities around the dam. The high chemical oxygen demand, Turbidity and Hardness in all the months could be due to the main pollution sources for example waste from mechanic workshops and battery charging shops, the municipal waste water, storm water runoffs, the A.B.U sewage treatment plant, abattoir effluents and irrigation farms treated with chemical fertilizers (Chigor et al., 2012) all these makes A.B.U reservoir vulnerable to chemical pollution. The mean monthly physicochemical properties of water samples for Galma dam showed variations in the parameters tested and were significant except for the COD. The variations could be as a result of run-offs from untreated discharge of pollutants from domestic sewers, storm water discharges, industrial wastewater, agricultural runoff and other various adjoining tributaries (most of which are seasonal); and contain myriads of toxic pollutant from few industrial activities in Chikaji and Dakace areas (Patrick et al., 2015) pollution from different sources of anthropogenic activities along the river banks which flows into the dam (Butu and Bichi, 2012). The mean monthly physicochemical properties of water samples for shika dam showed variations in the parameters tested and were significant except for the COD. The high chemical oxygen demand, Turbidity and Hardness in all the months could be as a result of agricultural runoff from farmlands; these carry organic and inorganic pollutants that are used in agriculture, most especially towards the end of the rainy season when pesticides are sprayed on farms around the university college dam, illegal dumping of refuse, animal waste, storm water runoff and non point source pollution.

In conclusion, the increased human population, industrialization, use of fertilizers 
in the agriculture and man-made activity has highly polluted the water bodies with different harmful contaminants in recent years. To this end, the findings of this research have demonstrated that the physicochemical parameters for Turbidity, Hardness and Chemical Oxygen Demand exceeded the permissible limits for the locations and months in all the dams. Other mean values for the physico-chemical parameters were within the acceptable limits Therefore, the water can be used for domestic and other sundry uses; and good for aquatic survival and adaptability. The dams are however, not fit for direct human consumption without treatment.

\section{Recommendation}

There is an urgent need for establishment of a Water Monitoring Programme (WMP) that will monitor the surface water of most dams in Nigeria so that routine monitoring of the water quality of the dams would ensure that these parameters are within the acceptable limits as the dams are constantly put to different usages due to the growing anthropogenic influences.

\section{References}

Adah, P.D. and Abok G. (2013). Challenges of Urban Water Management in Nigeria: The Way Forward. JESRM, 5(1): 111-121.

Adefemi, S.O. and Awokunmi, E.E. (2010), Determination of physico-chemical parameters and heavy metals in water samples from Itaogbolu area of OndoState, Nigeria. AJEST, 4(3):145-148.

Banwo, K.(2006).Nutrient load and pollution study of some selected stations along Ogunpa River in Ibadan, Nigeria. M.Sc. Dissertation, University of Ibadan, Nigeria.

Basavaraja, Simpi, S. M., Hiremath, K. N. S.
Murthy, K. N. Chandrashekarappa, Anil N. Patel, E.T. Puttiah, (2011) Analysis of Water Quality Using Physico-Chemical Parameters Hosahalli Tank in Shimoga District, Karnataka, India GJSF Research, 1(3), 31-34.

Butu, A.W. and Bichi, A.A. (2013). Assessment of some heavy elements in Galma dam, Zaria, Nigeria. IJDS, 2 (2): 686-696.

Chigor VN, Umoh VJ, Okuofu CA, Ameh JB, Igbinosa EO, Okoh AI (2012). Water quality assessment: surface water sources used for drinking and irrigation in Zaria, Nigeria are a public health hazard. EMA.; 184: 33893400 .

Fadaeifard, F., Raissy, M., Faghani, M. Majlesi, A and Farahani, G. N. (2012). Evaluation of physicochemical parameters of waste water from rainbow trout fish farms and their impacts on water quality of Koohrang stream - Iran IJFA Vol. 4(8): 170-177.

Genevieve M. C, James P. N. (2006). Water quality for ecosystem and human health, United Nations Environmental Programme Global Environment Monitoring System/Water Programme. http://www.gemswater. org

Mahesh, K.P. and Prabhahar, C. (2012). Physico - chemical parameters of river water: A review, IJPB, 3(6): 1304-1312.

NSDWQ, (2007). Nigerian Standard for Drinking Water. Nigerian Industrial Standard, NIS: 554, pp13-14.

Oyakhilome, G.I., Aiyesanmi, A.F., Akharaiyi, F.C., (2012). Water quality assessment of the Owena Multipurpose dam, Ondo State, Southwestern Nigeria. J.E. Protect. 3 (1), 14-25.

Okunlola I.A., Amadi A. N., Idris-Nda A., 
Agbasi K., and Kolawole L. L (2014). Assessment of Water Quality of Gurara Water Transfer from Gurara Dam to Lower Usuma Dam for Abuja Water Supply, FCT, Nigeria. AJWR, 2(4), 74-80

Patil, P.N., Sawant, D.V. and Deshmukh, R.N. (2012). Physico-chemical parameters for testing of water-A review. IJES 3(3): 1194-1207.

Patrick, O. S, John A. A, Bolanle S. (2015) Temporal and Spatial PhysicoChemical Parameters of River Galma, Zaria, Kaduna State, Nigeria, RE,. 4: $110-123$.

Sagar, S.S., Chavan, R.P., Patil, C.L., Shinde, D.N. and Kekane, S.S. (2015).
Physico-chemical parameters for testing of water-A review. IJCS, 3(4): 24-28.

Wakawa, R. J., Uzairu, A., Kagbu, J. A. and Balarabe, M. L. (2008). Impact assessment of effluent discharge on physico-chemical parameters and some heavy metal concentrations in surface water of River Challawa Kano, Nigeria. African JPAC.

World Health Organization (2008). Guidelines for Drinking-water Quality, Incorporating 1 st and 2nd Addenda, Volume 1 , Recommendations, 3rd ed.; WHO: Geneva, Switzerland.

\section{How to cite this article:}

Aregbe, E.A., O. S. Olonitola, H.I. Inabo, E.E. Ella and Ameso, V.C. 2018. Temporal and Spatial Physico-Chemical Parameters of Kubanni Dam, Galma Dam and Shika Dam, Zaria, Kaduna State, Nigeria. Int.J.Curr.Microbiol.App.Sci. 7(08): 812-822.

doi: https://doi.org/10.20546/ijcmas.2018.708.091 